\title{
Nutritional characteristics and quality of eggs from laying hens fed on a diet supplemented with chestnut tannin extract (Castanea sativa Miller)
}

\author{
S. Minieri, A. Buccioni, A. Serra, I. Galigani, A. Pezzati, S. Rapaccini \& M. \\ Antongiovanni
}

To cite this article: S. Minieri, A. Buccioni, A. Serra, I. Galigani, A. Pezzati, S. Rapaccini \& M. Antongiovanni (2016) Nutritional characteristics and quality of eggs from laying hens fed on a diet supplemented with chestnut tannin extract (Castanea sativa Miller), British Poultry Science, 57:6, 824-832, DOI: 10.1080/00071668.2016.1216944

To link to this article: http://dx.doi.org/10.1080/00071668.2016.1216944

Accepted author version posted online: 16 Sep 2016.

Published online: 10 Nov 2016.

Submit your article to this journal $₫$

Џ Article views: 63

Q View related articles $๘$

View Crossmark data \lceil 


\title{
Nutritional characteristics and quality of eggs from laying hens fed on a diet supplemented with chestnut tannin extract (Castanea sativa Miller)
}

\author{
S. MINIERI, A. BUCCIONI ${ }^{1}$, A. SERRA ${ }^{2}$, I. GALIGANI ${ }^{1}$, A. PEZZATI $^{1}$, S. RAPACCINI ${ }^{1}$, AND \\ M. ANTONGIOVANNI ${ }^{3}$
}

Department of Veterinary Science, University of Pisa, Pisa, Italy, ${ }^{1}$ Department of Agrifood Production and Enviromental Sciences, Animal Science Section, University of Florence, Florence, Italy, ${ }^{2}$ Department of Agricultural, Food and Agroenvironmental, University of Pisa, Pisa, Italy, and ${ }^{3}$ Gruppo Mauro Saviola, Mantova, Italy

\begin{abstract}
The trial was performed with 80 laying hens belonging to two Tuscan autochthonous breeds: 40 birds of the Mugellese (MU) breed and 40 of the White Leghorn (WL) breed.

2. The animals were allotted to 4 groups of individually caged 20 hens each: two groups were fed on a commercial diet and worked as the control groups (MUC and WLC); the other two groups received the same diet, integrated with $2 \mathrm{~g}$ of chestnut tannin (CT) extract per $\mathrm{kg}$ of diet (MUT and WLT).

3. A sample of 70 eggs were randomly collected and analysed for cholesterol content, fatty acid (FA) profile, weight, thickness of shell and colour of yolk.

4. Physical parameters, including yolk colour, and indices of egg quality were not affected by the treatments.

5. The concentration of unsaturated FAs increased, whereas cholesterol was significantly decreased: $-17 \%$ in WLT and $-9 \%$ in MUT. Dietary supplementation with CT extract resulted in a modification of lipid composition, towards a more healthy quality of eggs.
\end{abstract}

\section{INTRODUCTION}

The world daily consumption of eggs is high because eggs are an inexpensive source of nutrition and because they are ingredients for many food products. Hence, eggs are considered the primary source of cholesterol in the human diet. Studies on lipid metabolism have shown that most of the egg cholesterol is synthesised in the liver and is used essentially for embryonic development (Naber, 1976). Cholesterol and its esters, therefore, are found only in yolks where they are emulsified by high-, low- and very-low-density lipoproteins. The literature reported that egg cholesterol is strongly influenced either by genetic factors or by lay intensity, and hens belonging to high-producing breeds produce eggs with a lower cholesterol content compared to eggs from autoctonous breeds, characterised by a lower daily egg production (NRC, 1994). Despite conflicting evidence about the role of dietary cholesterol in cardiovascular diseases, many efforts have been made to reduce its content in eggs by genetic approaches and by new feeding strategies (Milinsk et al., 2003). Several authors demonstrated that the fibre percentage in the diet plays an important role in reducing the cholesterol in yolks, especially if associated with a low supplementation of vegetable oils (Naber, 1976; McNaughton et al., 2014). Also, the dietary integration of probiotics like Lactobacillus sporogenes showed positive results in limiting cholesterol in eggs (Panda et al., 2008). The literature reported that hydrolysable polyphenols are able to reduce the cholesterol synthesis in monogastrics including humans, interfering with lipid metabolism at the liver level and that the gallic acid moiety is important in these inhibitory activities ( $\mathrm{Lu}$ and Hwang, 2008; Kim et al., 2013; Kobayashi and Ikeda, 2014). Tannins extracted from chestnut wood (Castanea sativa Miller), a common plant species in the Mediterranean area, are an 
example of hydrolysable polyphenols characterised by the presence of the gallic acid moiety (Campo et al., 2012). However, the use of tannins in poultry feeding is limited by their anti-nutritional effect responsible for the decrease of organic matter digestibility and, consequently, of decreased growth performance or egg production (Chang and Fuller, 1964; Ahmed et al., 1991; Longstaff and McNab, 1991a, 1991b; Trevino et al., 1992; Giner-Chavez, 1996; Smulikowska et al., 2001; Garcia et al., 2004). The literature reported controversial data probably because tannin properties are strongly linked to their origin and some of them, when used in appropriate doses, may help prevent undesired intestinal microflora development (Scalbert, 1991; Chung et al., 1998). Several authors, investigating the influence of the polyphenol extract from chestnut wood, found that the use of these substances in poultry feeding did not affect nitrogen balance, nutrient digestibility, mineral bioavailability, body weight, feed conversion ratio and carcass quality (Salobir et al., 2008; Schiavone et al., 2008; Jamroz et al., 2009). Moreover, chestnut tannins (CTs) are also efficient against coccidiosis and necrotic enteritis in poultry (Elizondo et al., 2010; BoleHribovsek et al., 2012; Tosi et al., 2013). In contrast, little information is reported on the role of CT in laying hens' feeding because most of the studies deal with the use of condensed tannins (Sell et al., 1983; Jacob et al., 1996; Marzoni et al., 2005; Imik, 2009).

Hens' sensitivity to dietary tannins varies according to their ability to denature these compounds with digestive enzymes, and several authors observed a marked decrease in egg production and an increased frequency of egg yolk mottling also at low inclusion levels in the diet (Chang and Fuller, 1964; Vohra et al., 1966; Fuller et al., 1967; Begovic et al., 1978).

Consequently, the aim of the current study was to investigate the effects of a commercial chestnut tannin extract (CTE) from Castanea sativa Miller, on cholesterol content and nutritional quality of eggs from two breeds of laying hens characterised by a different productive performance, White Leghorn vs. Mugellese.

\section{METHODS}

\section{Animals, environment, experimental design and diets}

All experimental procedures were approved by the Ethics Committee of the University of Florence and were in compliance with the guidelines of the International Animal Care and Use Committee (IACUC, 2004) for the care and use of animals in research.
The trial was performed with 80 laying hens (aged 39 weeks), 40 belonging to the dwarf breed Mugellese (MU) breed and 40 to the White Leghorn (WL) breed.

These two breeds were chosen because they are characterised by different productive performances. WL is a cosmopolitan breed being good layers of white eggs and characterised by a good feed-to-egg conversion ratio. In contrast, MU is a small local population very appreciated by consumers for their egg quality, characterised by a lower daily egg production than WL.

The birds were weighed and individually allotted in 80 pens (20 pens per each experimental group; one bird was considered as replicate) and maintained under semi-controlled environmental conditions with exposure to a $16 \mathrm{~h}$ photoperiod in a 2x2 factorial design. For each breed, a group was fed on a control diet (groups MUC and WLC; $603.5 \pm 4.4 \mathrm{~g}$ and $2315.7 \pm 22.5 \mathrm{~g}$ of life body weight, respectively); the other group (groups MUT and WLT; $603.9 \pm 7.0 \mathrm{~g}$ and $2313.7 \pm 34.3 \mathrm{~g}$ of life body weight, respectively) received the same diet, integrated with $2 \mathrm{~g}$ of a commercial CTE (Saviotan feed ${ }^{\circ}$, provided by Gruppo Mauro Saviola - Mantova - Italy) per $\mathrm{kg}$ of diet, expressed on dry matter (DM). CTE contained $750 \mathrm{~g}$ of tannic acid equivalents $/ \mathrm{kg}$ of $\mathrm{DM}$ and was titrated according to Burns (1963). The CTE chemical composition has been previously investigated by Campo et al. (2012). The diets used in this trial were administered as pellets and were formulated to meet the nutrient requirements of laying hens consuming $100 \mathrm{~g}$ of feed per day according to National Research Council (NRC, 1994). The trial lasted 5 weeks, after a 4-week preliminary adaptation period. The ingredients and the chemical composition of the diets are shown in Table 1 .

Diets and water were administered ad libitum during the study and dietary consumption was measured daily for each hen considering the amount of feed offered and the residuals. Individual animal body weights were measured at the beginning and at the end of the experimental period.

\section{Collection of eggs}

Egg production was recorded for the entire 35-d period for each hen and the percent hen-day egg production (HDEP\%) was calculated according to the formula published by North (1984):

\section{(HDEP\% $=$ Number of eggs produced on daily basis/ \\ Number of birds available in the flock on that d) x100}

All eggs produced were collected daily to be weighed and measured with a digital compass to 
Table 1. Ingredients and chemical composition of control $(C)$ and treatment $(T)$ diets

\begin{tabular}{|c|c|c|c|}
\hline & & Diet $C^{1}$ & Diet $\mathrm{T}^{1}$ \\
\hline \multicolumn{4}{|l|}{ Ingredients } \\
\hline Maize meal & $\mathrm{g} / \mathrm{kg}$ & 337.8 & 337.8 \\
\hline Rice bran & “ & 185.0 & 185.0 \\
\hline Soybean meal & “ & 308.3 & 308.3 \\
\hline Soybean oil & “ & 95.2 & 95.2 \\
\hline Limestone & “ & 14.5 & 14.5 \\
\hline Calcium phosphate & “ & 40.1 & 40.1 \\
\hline Vitamin and mineral premix ${ }^{2}$ & “ & 1.50 & 1.50 \\
\hline Lysine-HCl & “ & 2.1 & 2.1 \\
\hline Chestnut extract tannin ${ }^{3}$ & “ & - & 2.0 \\
\hline Bentonite & “ & 2.0 & - \\
\hline \multicolumn{4}{|l|}{ Chemical composition } \\
\hline $\mathrm{DM}^{4}$ & $\mathrm{~g} / \mathrm{kg}$ & 945.0 & 945.0 \\
\hline $\mathrm{CP}^{5}$ & $\mathrm{~g} / \mathrm{kg} \mathrm{DM}$ & 188.1 & 188.1 \\
\hline $\mathrm{NDF}^{6}$ & “ & 109.2 & 109.2 \\
\hline $\mathrm{CF}^{7}$ & “ & 47.3 & 47.3 \\
\hline $\operatorname{Ash}^{8}$ & “ & 55.5 & 55.5 \\
\hline $\mathrm{GE}^{9}$ & $\mathrm{MJ} / \mathrm{kg} \mathrm{DM}$ & 15.6 & 15.6 \\
\hline Tannic acid equivalent & $\mathrm{g} / \mathrm{kg} \mathrm{DM}$ & - & 1.5 \\
\hline \multicolumn{4}{|c|}{ Fatty acid profile (g/100 g of total fatty acids) } \\
\hline C16:0 & & 9.60 & 9.58 \\
\hline C18:0 & & 3.41 & 3.45 \\
\hline C18:1 cis-9 & & 22.60 & 22.64 \\
\hline C18:2 cis-9 cis-12 & & 54.32 & 54.29 \\
\hline C18:3 cis-9 cis-12 cis-15 & & 6.90 & 6.88 \\
\hline Others & & 3.17 & 3.16 \\
\hline
\end{tabular}

${ }^{1}$ Diet $\mathrm{C}$, control diet; diet $\mathrm{T}$, diet supplemented with chestnut tannin extract.

${ }^{2}$ The vitamin and mineral mixture provided per kg of diet: cholecalciferol, $180000 \mathrm{mg}$; vitamin E (DL- $\alpha$-tocopheryl acetate), $4000 \mathrm{mg}$; retinol (retinyl acetate), $1620000 \mathrm{mg}$; menadione, $300 \mathrm{mg}$; thiamine $120 \mathrm{mg}$; riboflavin, $180 \mathrm{mg}$; pyridoxine, $120 \mathrm{mg}$; folic acid, $100 \mathrm{mg}$; biotin, $200 \mu \mathrm{g}$; cyanocobalamin, $20 \mu \mathrm{g}$; Calcium-D pantothenate, $1.08 \mathrm{~g}$; $\mathrm{FeCO}_{3}, 4000 \mathrm{mg} ; \mathrm{ZnO}$, $5000 \mathrm{mg} ; \mathrm{MnO}, 6000 \mathrm{mg}$; $\mathrm{CuSO}_{4} .5 \mathrm{H}_{2} \mathrm{O}, 300 \mathrm{mg}$; KI, $1000 \mu \mathrm{g} ; \mathrm{Na}_{2} \mathrm{SeO}_{3}$, $200 \mu \mathrm{g}$ and $\mathrm{CoCO}_{3}, 200 \mu \mathrm{g}$.

${ }^{3}$ SaviotaN ${ }^{\circledR}$, provided by Gruppo Mauro Saviola - Radicofani - Si- Italy. $\mathrm{DM}^{4}$, dry matter ${ }^{5}$; $\mathrm{CP}^{6}$, crude protein; $\mathrm{NDF}^{7}$, neutral detergent fibre assayed with a heat-stable amylase and expressed inclusive of residual ash; $\mathrm{CF}^{8}$, crude fat; $\mathrm{GE}^{9}$, gross energy.

obtain both short and long diameters as well as thickness of shells at a $\pm 0.001 \mathrm{~mm}$ sensitivity.

During the whole experimental period, 70 eggs from each group were randomly collected; for each egg the yolk and albumen were separated and, immediately after the collection, assayed for chemical and physical characteristics as described below.

\section{Proximate analysis of diets and eggs}

Samples of feeds (in triplicate for each treatment) were analysed for DM, crude protein (CP), ash and ether extract (EE) according to the 930.15, 976.06, 942.05 and 920.39 procedures of AOAC (1995), respectively, while neutral detergent fibre (NDF) of the diets was determined according to Van Soest et al. (1991) using heat-stable amylase and expressed inclusive of residual ash. The gross energy (GE) value was calculated according to NRC (1994). Fresh individual samples of yolk and albumen (70 for each treatment) were analysed for CP and ash according to the 976.06 and 942.05 procedures of AOAC (1995). Fat content was determined gravimetrically according to Folch et al. (1957) at the moment of lipid extraction for fatty acid (FA) profile characterisation as described below.

\section{Determination of FA profile of diets and yolk}

Diets ( 2 g; in triplicate for each treatment) were analysed for FA profile using a one-step methylation procedure according to Sukhija and Palmquist (1988). Fresh samples (200 mg) of yolk (70 from each experimental group) were extracted for total lipids content according to Folch et al. (1957) and FA composition was determined after a double-step esterification according to Kramer et al. (2004).

The fatty acid methyl esters (FAME) were separated by a GC equipped with an FID detector and a capillary column (CP-Select CB for FAME Varian, Middelburg, The Netherlands: $100 \mathrm{~m} \mathrm{x}$ $0.25 \mathrm{~mm}$ i.d.; film thickness $0.20 \mathrm{um}$ ). The injector and FID detector temperatures were, respectively, $270^{\circ} \mathrm{C}$ and $300^{\circ} \mathrm{C}$. The oven programmed temperature was $40^{\circ} \mathrm{C}$ for $4 \mathrm{~min}$, increased to $120^{\circ} \mathrm{C}$ at a rate of $10^{\circ} \mathrm{C} \min ^{-1}$, maintained at $120^{\circ} \mathrm{C}$ for $1 \mathrm{~min}$, increased to $180^{\circ} \mathrm{C}$ at a rate of $5^{\circ} \mathrm{C} \mathrm{min} \mathrm{m}^{-1}$, maintained at $180^{\circ} \mathrm{C}$ for $18 \mathrm{~min}$, increased to $200^{\circ}$ $\mathrm{C}$ at a rate of $2^{\circ} \mathrm{C} \mathrm{min}^{-1}$, maintained at $200^{\circ} \mathrm{C}$ for $1 \mathrm{~min}$, increased to $230^{\circ} \mathrm{C}$ at a rate of $2^{\circ} \mathrm{C} \mathrm{min}{ }^{-1}$ and maintained at this last temperature for $19 \mathrm{~min}$. The split ratio was 1:100 and helium was the carrier gas with a flux of $1 \mathrm{ml} \mathrm{min}^{-1}$. Individual FAMEs were quantified using valeric acid (C5:0) and non-adecanoic acid (C19:0) methyl esters (cods 14899 and N5377, respectively; SigmaAldrich Chemical Co., St. Louis, MO) as internal standards and identified by comparison to the relative retention times of FAME peaks from samples, with those of the standard mixture 37 Component FAME Mix C4:0-C24:0 (cod 18919-1AMP, Supelco, Bellefonte, PA), individual trans-9 C18:1 and trans-11 C18:1 (cods 46903 and v1381 respectively, Sigma-Aldrich Chemical Co., St. Louis, MO), individual cis-9, trans-11 C18:2 (cod 1255, Matreya Inc, Pleasant GAP, PA), conjugated linoleic acid (CLA) mix standard (cod 05632, Sigma-Aldrich Chemical Co., St. Louis, MO) and published isomeric profiles (Kramer et al., 1997, 2004; Cruz-Hernandez et al., 2006). The C18:1 isomers elution sequence was performed according to Kramer et al. (2008). Moreover, standard mix of $\alpha$-linolenic acid $(\alpha-$ LNA) isomers (cod 47792, Supelco, Bellefonte, PA) and of linoleic acid (LA) isomers (cod 47791, Supelco, Bellefonte, PA) and published isomeric profiles (Destaillats et al., 2005) were used to identify the isomers of interest. Two bacterial acid methyl ester mixes (cod 47080-U 
Supelco, Bellefonte, PA; cod GLC110, Matreya, Pleasant Gap, PA) and individual standard for methyl ester of iso C14:0, anteiso C14:0, iso C15:0 and anteiso C17:0 (cods 21-1211-11, 21-1210-11, 21-1312-11 and 21-1415-11, respectively, Larodan Malmo, Sweden) were used to identify the branched FA profile. Inter- and intra-assay coefficients of variation were calculated by using a reference standard butter (cod CRM 164, Community Boureau of Reference, Bruxelles, Belgium) and the detection threshold was $0.1 \mathrm{~g} / \mathrm{kg}$ of $\mathrm{FA}$ (Contarini et al., 2013). All results were expressed as $\mathrm{g} / \mathrm{kg}$ of total lipids. Intra-assay coefficients of variation ranged from 0.5 to $1.5 \%$, whereas interassay coefficients of variation ranged from 1.5 to 2.5 .

Desaturation index (DI) was calculated considering the concentration of C14:0 and cis -9 C14:1 FA according to the following formula (Buccioni et al., 2015):

$$
\mathrm{DI}=c i s-9 \mathrm{C} 14: 1 /(c i s-9 \mathrm{C} 14: 0+\mathrm{C} 14: 1)
$$

\section{GC analysis of cholesterol}

Fresh samples $(500 \mathrm{mg}$ ) of yolk (70 from each experimental group) were individually analysed for total sterols (free and esterified) obtained after cold saponification according to Sander et al. (1989). Gaschromatographic analysis of cholesterol was carried out using a capillary column (SE 52, Macherey-Nagel GmbH \& Co KG, Germany; $50 \mathrm{~m} \times 0.25 \mathrm{~mm}$ ID, film thickness $0.25 \mu \mathrm{m})$ with the temperature being programmed from 220 to $310^{\circ} \mathrm{C}$ at a rate of $4.5^{\circ} \mathrm{C} /$ min. Both injector and detector temperatures were set at $350^{\circ} \mathrm{C}$ (Sweeley et al., 1963).

\section{Colour analysis}

Yolks (70 from each experimental group) were poured into a clean glass petri dish to be measured for colour using the portable spectrophotometer (Minolta CR 200 Chroma Meter 4, calibrated using a standard yellow calibration tile, model CRA471). The top of the Chroma Meter measuring head was placed flat against the surface of yolk and reflective colour was determined from the average of three consecutive pulses from the optical chamber of the spectrophotometer. Data are reported in the $L^{*} a^{*} b^{*}$ colour notation system with the $L^{*}$ axis representing lightness, the $a^{*}$ axis representing the red-green colour axis (redness) and the $b^{*}$ axis representing the blue-yellow (yellowness) colour axis (Minolta, 1994).

\section{Statistical analysis}

All data (e.g., animal weight and physical parameters, composition and FA profile of eggs) recorded over the course of the experiment were processed as a full factorial design with repeated measures using the MIXED procedure of SAS (1999):

$$
y_{i j k l}=\mu+D_{i}+B_{j}+I_{k}(D)+(D \times B)_{i j}+e_{i j k l}
$$

where $y_{\mathrm{ijkl}}$ is the observation; $\mu$ is the overall mean; $\mathrm{D}_{\mathrm{i}}$ the fixed effect of diet $(i=1-3) ; B_{j}$ the fixed effect of Breed $(j=1-2) ; \mathrm{I}_{\mathrm{k}}$ is the random effect of the hen nested within the diet $(k=1-20) ;(D \times B)_{i j}$ is the interaction between diet and breed and $e_{i j k l}$ is the residual error. The covariance structure was compound symmetry, which was selected on the basis of Akaike's information criterion of the mixed model of SAS. Statistical significance of the diet effect was tested against variance of hen nested within diet according to a repeated-measures design theory (Littell et al., 1998).

Data related to percent hen-d egg production were processed with GLM using the MIXED procedures of SAS (1999):

$$
y_{i j l}=\mu+D_{i}+B_{j}+(D \times B)_{i j}+e_{i j k l}
$$

where $y_{i j l}$ is the observation; $\mu$ is the overall mean; $D_{i}$ the fixed effect of diet $(i=1-3) ; B_{\mathrm{j}}$ the fixed effect of Breed $(j=1-2) ;(D \times B)_{i j}$ the interaction between diet and breed and $\mathrm{e}_{\mathrm{ijkl}}$ the residual error.

\section{RESULTS}

\section{Feed intake, egg production and egg quality}

During the experimental period no animal loss was registered. Moreover, no differences in average dry matter intake (DMI) were found in the treated groups compared to their related control groups $($ MUC $=93.02 \mathrm{~g} /$ head and $d$ vs. MUT $=97.93 \mathrm{~g} /$ head and $d$, s.e.m 2.65, $P=0.732 ; \quad$ WLC $=120.34 \mathrm{~g} / \mathrm{head}$ and $d$, $\mathrm{WLT}=118.32 \mathrm{~g} / \mathrm{head}$ and $d$, s.e.m. 1.99, $P=0.902)$. At the end of the trial, no variation either in body weight or in egg production was registered as a consequence of a $D$ effect (Table 2). Instead, a $B$ effect for animal body weight, per cent hen-d egg production and their physical characteristics was observed according to the higher live-weight and better performances of WL compared to that of MU (Table 2). The yolk colour and shell thickness were not affected by $D$, $B$ or by their interaction $D \times B$ (Table 3). Only a significant $B$ effect was found for yolk and albumen protein, fat and ash contents, which were higher in eggs from MU than from WL (Table 3).

\section{FA profile and cholesterol content of eggs yolk}

Yolk FA composition was affected by CTE for both breeds of laying hens (Table 4). The main effects 
Table 2. Influence of diet on egg production and egg quality from hens consuming chestnut tannin extract (data shown are the means of 70 replicates)

\begin{tabular}{|c|c|c|c|c|c|c|c|c|}
\hline & \multicolumn{2}{|c|}{ Mugellese } & \multicolumn{3}{|c|}{ White Leghorn } & \multicolumn{2}{|c|}{$P$-value ${ }^{2}$} & \multirow[b]{2}{*}{$D \times B$} \\
\hline & ${ }^{3} \mathrm{MUC}$ & ${ }^{3} \mathrm{MUT}$ & ${ }^{3} \mathrm{WLC}$ & ${ }^{3} \mathrm{WLT}$ & $\mathrm{SEM}^{1}$ & $D$ & $B$ & \\
\hline Hen weight $(g)$ & 604.7 & 604.0 & 2319.0 & 2320.8 & 6.26 & 0.867 & $<0.0001$ & 0.781 \\
\hline Per cent hen-day egg production (\%) & 56.6 & 55.1 & 72.2 & 71.6 & 0.78 & 0.173 & $<0.0001$ & 0.649 \\
\hline Egg weight $(\mathrm{g})$ & 31.9 & 33.0 & 49.3 & 51.1 & 1.44 & 0.323 & $<0.0001$ & 0.787 \\
\hline Egg shell thickness (mm) & 0.4 & 0.4 & 0.4 & 0.4 & 0.02 & 0.402 & 0.086 & 0.310 \\
\hline \multicolumn{9}{|l|}{$g / 100 \mathrm{~g}$ on $\mathrm{DM}$} \\
\hline Yolk crude protein & 28.31 & 28.52 & 29.38 & 29.73 & 4.12 & 0.508 & 0.016 & 0.508 \\
\hline Albumen crude protein & 82.03 & 82.15 & 83.61 & 83.92 & 2.73 & 0.600 & 0.021 & 0.927 \\
\hline Yolk crude fat & 58.07 & 58.65 & 55.82 & 55.15 & 7.34 & 0.948 & 0.002 & 0.412 \\
\hline Albumen crude fat & 0.13 & 0.13 & 0.11 & 0.12 & 0.91 & 0.847 & 0.011 & 0.723 \\
\hline Yolk ash & 3.34 & 3.02 & 3.95 & 3.57 & 2.14 & 0.130 & 0.019 & 0.886 \\
\hline Albumen ash & 5.31 & 5.62 & 5.44 & 5.58 & 1.93 & 0.567 & 0.042 & 0,756 \\
\hline Cholesterol & $2.317 \mathrm{a}$ & $2.117 \mathrm{~b}$ & $2.478 \mathrm{a}$ & $2.066 \mathrm{~b}$ & 1.13 & 0.041 & 0.615 & 0.025 \\
\hline
\end{tabular}

${ }^{1}$ Standard error of the mean.

${ }^{2}$ Probability of a significant effect due to experimental diet $(D)$, breeds $(B)$ and their interaction $D \times B$.

${ }^{3}$ MUC, Mugellese hens fed on the control diet; MUCT, Mugellese hens fed the diet supplemented with chestnut tannin extract; WLC, White Leghorn hens fed the control diet; WLT, White Leghorn hens fed the diet supplemented with chestnut tannin extract.

${ }^{\mathrm{a}-\mathrm{c}}$ Means within a row with no common superscript letter differ significantly $(P<0.05)$.

Table 3. Influence of diet on yolk colour (data shown are the means of 70 replicates)

\begin{tabular}{|c|c|c|c|c|c|c|c|c|}
\hline \multirow[b]{2}{*}{ Colour } & \multicolumn{2}{|c|}{ Mugellese } & \multicolumn{2}{|c|}{ White Leghorn } & \multirow[b]{2}{*}{$\mathrm{SEM}^{1}$} & \multicolumn{3}{|c|}{$P$-value ${ }^{2}$} \\
\hline & ${ }^{3} \mathrm{MUC}$ & ${ }^{3} \mathrm{MUT}$ & ${ }^{3} \mathrm{WLC}$ & ${ }^{3} \mathrm{WLT}$ & & $D$ & $B$ & $D \times B$ \\
\hline $\mathrm{L}^{*}$ & 58.2 & 56.7 & 57.9 & 57.9 & 1.19 & 0.554 & 0.720 & 0.521 \\
\hline$a^{*}$ & 4.3 & 4.7 & 5.1 & 4.9 & 0.41 & 0.840 & 0.190 & 0.633 \\
\hline $\mathrm{b}^{*}$ & 39.8 & 38.6 & 39.9 & 40.4 & 2.17 & 0.863 & 0.669 & 0.706 \\
\hline
\end{tabular}

${ }^{1}$ Standard error of the mean.

${ }^{2}$ Probability of a significant effect due to experimental diet $(D)$, breeds $(B)$ and their interaction $D \times B$.

${ }^{3}$ MUC, Mugellese hens fed on the control diet; MUCT, Mugellese hens fed the diet supplemented with chestnut tannin extract; WLC, White Leghorn hens fed on the control diet; WLT, White Leghorn hens fed on the diet supplemented with chestnut tannin extract.

were found for unsaturated fatty acid (UFA). In fact, the dietary inclusion of CTE increased cis-9 C16:1 (palmitoleic acid, PO) and decreased cis-9, cis-12 C18:2 (LA) contents with a significant effect due to the $D$ and $B$ factors and their interaction $D \times B(P<0.05)$. In contrast, cis-9 C18:1 (oleic acid, OA) was enhanced in MUT and WLT with a significant effect of the $D$ factor and interaction $D \times B$, but not of $B$. The interaction $D \times B$ was significant for C16:0 (palmitic acid, PA), which decreased in MUT and increased in WLT compared to the related control groups. The Cis -9 C14:1 concentration was decreased by CTE inclusion in the diet only in yolk from MUT compared to WLT. Only WLT showed a significant decrease of iso C17:0, C18:0 (stearic acid, SA) and cis-11 cis14 C20:2. Instead, the concentration of LA decreased in both WLT and MUT. The contents of cis-5 cis-8 cis-11 cis-14 cis-17 C20:5 (eicosapentaenoic acid, EPA) and cis-4 cis-7 cis-10 cis-13 cis-16 cis19 C22:6 (docosahexaenoic acid, DHA) remained constant regardless of breed or CTE dietary supplementation. In addition, the cis-5 cis-8 cis-11 cis-
14 C20:4 (arachidonic acid, AA) content remained constant in the two groups of eggs for both breeds of hens.

Considering DI, this parameter was affected by $D$ and showed an opposite trend (significant effect of $D \times B$ ) in the treated groups because it decreased significantly in MUT while it increased in WLT.

The main effect on the lipid fraction resulted in a cholesterol content that tended to decrease in the group treated with CTE, regardless of breed and with significant $D$ and $D \times B$ effects (Table 2).

\section{DISCUSSION}

No differences were observed in DMI between hens fed control or CTE diets. As a consequence, the inclusion of CTE in the diets at $20 \mathrm{~g} / \mathrm{kg}$ did not affect the dietary palatability. Moreover, the differences found in egg production and egg weight were due only to the breed effect according to the better performance of WL compared to MU and not to the 
Table 4. Fatty acid profile of yolk ( $\mathrm{g} / 100 \mathrm{~g}$ of total lipids; data shown are the means of 70 replicates)

\begin{tabular}{|c|c|c|c|c|c|c|c|c|}
\hline \multirow[b]{2}{*}{ Fatty acid } & \multicolumn{2}{|c|}{ Mugellese } & \multicolumn{2}{|c|}{ White Leghorn } & \multirow[b]{2}{*}{$\mathrm{SEM}^{1}$} & \multicolumn{3}{|c|}{$P$-value ${ }^{2}$} \\
\hline & ${ }^{3} \mathrm{MU}$ & ${ }^{3} \mathrm{MUT}$ & ${ }^{3} \mathrm{WL}$ & ${ }^{3} \mathrm{WLT}$ & & $D$ & $B$ & $D \times B$ \\
\hline C14:0 & 0.201 & 0.251 & 0.268 & 0.239 & 0.33 & 0.764 & 0.450 & 0.284 \\
\hline C14:1 cis-9 & $0.082 \mathrm{a}$ & $0.033 b$ & $0.040 \mathrm{~b}$ & $0.038 \mathrm{~b}$ & 0.10 & 0.337 & 0.615 & 0.045 \\
\hline C15:0 & 0.049 & 0.056 & 0.070 & 0.057 & 0.11 & 0.824 & 0.369 & 0.391 \\
\hline C15:1 trans -9 & 0.107 & 0.082 & 0.082 & 0.111 & 0.15 & 0.891 & 0.882 & 0.134 \\
\hline C16:0 & $24.264 b$ & $24.041 c$ & $23.000 \mathrm{~d}$ & $24.849 \mathrm{a}$ & 0.80 & 0.174 & 0.689 & 0.043 \\
\hline C16:1 cis-9 & $1.673 \mathrm{c}$ & $1.739 \mathrm{~b}$ & $1.473 \mathrm{~d}$ & $2.009 \mathrm{a}$ & 0.21 & 0.025 & 0.037 & 0.043 \\
\hline C17iso & $0.039 \mathrm{~b}$ & $0.032 b$ & $0.056 \mathrm{a}$ & $0.016 \mathrm{c}$ & 0.08 & 0.015 & 0.948 & 0.048 \\
\hline C17ante & 0.064 & 0.037 & 0.071 & 0.037 & 0.23 & 0.249 & 0.894 & 0.888 \\
\hline C17:0 & 0.215 & 0.218 & 0.221 & 0.163 & 0.60 & 0.261 & 0.276 & 0.260 \\
\hline C17:1 cis-9 & $0.056 \mathrm{~b}$ & $0.071 \mathrm{a}$ & $0.051 b$ & $0.044 b$ & 0.09 & 0.723 & 0.122 & 0.026 \\
\hline C18:0 & $11.813 \mathrm{~b}$ & $11.761 \mathrm{~b}$ & $12.409 \mathrm{a}$ & $10.779 \mathrm{c}$ & 0.31 & 0.723 & 0.121 & 0.026 \\
\hline C18:1 trans-9 & 0.094 & 0.108 & 0.335 & 0.101 & 0.95 & 0.293 & 0.263 & 0.240 \\
\hline C18:1 cis-9 & $3.0651 b$ & $3.2677 \mathrm{a}$ & $2.9343 b$ & $3.2078 \mathrm{c}$ & 0.81 & 0.041 & 0.489 & 0.046 \\
\hline C18:1 cis- 11 & 1.277 & 1.413 & 1.413 & 1.291 & 0.93 & 0.961 & 0.963 & 0.399 \\
\hline C18:2 trans -9, trans -12 & $0.041 b$ & $0.040 \mathrm{~b}$ & $0.061 \mathrm{a}$ & $0.029 \mathrm{c}$ & 0.07 & 0.046 & 0.555 & 0.050 \\
\hline C18:2 cis-9, cis-12 & $14.986 \mathrm{~b}$ & $14.275 \mathrm{c}$ & $15.908 \mathrm{a}$ & $14.602 \mathrm{~b}$ & 0.90 & 0.049 & 0.034 & 0.049 \\
\hline C18:3 cis-9, cis-12, cis-15 & $0.183 a$ & $0.114 b$ & $0.058 \mathrm{c}$ & $0.115 b$ & 0.11 & 0.011 & 0.080 & 0.046 \\
\hline C20:0 & 0.051 & 0.038 & 0.048 & 0.028 & 0.06 & 0.014 & 0.305 & 0.371 \\
\hline C20:1 cis-11 & 0.118 & 0.154 & 0.124 & 0.133 & 0.01 & 0.069 & 0.557 & 0.269 \\
\hline $\mathrm{C} 20: 2$ cis- 11 , cis-14 & $0.133 \mathrm{~b}$ & $0.137 b$ & $0.174 \mathrm{a}$ & $0.116 \mathrm{~b}$ & 0.14 & 0.047 & 0.479 & 0.045 \\
\hline C20:3 cis-11, cis-14, cis-17 & $0.211 \mathrm{a}$ & $0.210 \mathrm{a}$ & $0.154 \mathrm{c}$ & $0.181 b$ & 0.04 & 0.045 & 0.142 & 0.042 \\
\hline C20:4 cis-5, cis-8, cis-11, cis-14 & 3.516 & 4.210 & 4.201 & 3.381 & 4.02 & 0.882 & 0.871 & 0.097 \\
\hline $\mathrm{C} 22: 1$ cis-15 & 0.064 & 0.055 & 0.064 & 0.045 & 0.08 & 0.153 & 0.585 & 0.589 \\
\hline C20:5 cis-5, cis-8, cis-11, cis-14, cis-17 & 0.071 & 0.037 & 0.054 & 0.042 & 0.14 & 0.160 & 0.721 & 0.514 \\
\hline C24:0 & 0.045 & 0.050 & 0.042 & 0.057 & 0.12 & 0.448 & 0.892 & 0.673 \\
\hline C24:1 cis-15 & 0.095 & 0.067 & 0.041 & 0.061 & 0.17 & 0.834 & 0.043 & 0.187 \\
\hline C22:6n3 cis-4, cis-7, cis-10, cis-13, cis-16 & 1.615 & 1.769 & 2.102 & 1.554 & 0.27 & 0.466 & 0.612 & 0.208 \\
\hline SFA & $36.638 \mathrm{a}$ & $36.415 \mathrm{a}$ & $36.058 b$ & $36.172 b$ & 0.81 & 0.049 & 0.452 & 0.321 \\
\hline MUFA & $34.217 \mathrm{a}$ & $36.399 \mathrm{~b}$ & $32.966 \mathrm{~d}$ & 35.911c & 0.43 & 0.031 & 0.563 & 0.654 \\
\hline PUFA & 20.644ab & $20.715 \mathrm{ab}$ & $22.597 \mathrm{a}$ & $19.949 b$ & 0.99 & 0.134 & 0.721 & 0.321 \\
\hline $\mathrm{DI}^{4}$ & $0.289 \mathrm{a}$ & $0.116 b$ & $0.129 \mathrm{~b}$ & $0.137 b$ & 0.34 & 0.032 & 0.661 & 0.162 \\
\hline
\end{tabular}

${ }^{1}$ Standard error of the mean.

${ }^{2}$ Probability of a significant effect due to experimental diet $(D)$, breeds $(B)$ and their interaction $D \times B$; a, b, c, d indicate $P<0.05$.

${ }^{3}$ MUC, Mugellese hens fed on the control diet; MUCT, Mugellese hens fed on the diet supplemented with chestnut tannin extract; WLC, White Leghorn hens fed on the control diet; WLT, White Leghorn hens fed on the diet supplemented with chestnut tannin extract.

${ }^{4}$ Desaturation index, calculated as C14:1 cis-9 /(C14:1 cis-9 + C14:0).

${ }^{\text {a-c }}$ Means within a row with no common superscript letter differ significantly $(P<0.05)$.

dietary supplementation of CTE. WL, in fact, is largely distributed in the world for its high productivity and for its good feed-to-egg conversion ratio, also when reared in free-range farming. In contrast, MU is a small population, particularly adapted for a free-range management but with medium productivity, even if appreciated by consumers for the egg quality. The literature reported that tannins can interfere with calcium absorption in hens, affecting the shell thickness (Salobir et al., 2008). In the present study this parameter was not changed among groups, suggesting that presumably the bioavailability of calcium is ensured also in animals fed on diets supplemented with CTE. Moreover, in this trial CTE supplementation did not cause discolouration and mottling in yolks, suggesting that CTE did not interfere with pigment metabolism. This is in contrast to what has been found in other studies that reported the passage of undesirable pigments from gut to yolk when condensed polyphenols were added to feed at a concentration comparable to that used in the present experiment (Potter, 1967; Weber, 1970; Hughes, 1972). No differences were observed in the CP content of eggs among groups, regardless of diet or breed. The literature reported controversial data on the effect of tannins in poultry feeding and it could be related to the dose and the kind of tannin used in the trials as a consequence of their chemical structure and their solubility strongly linked to their chemical structure. Observing the FA profile of yolks, the absorption of MUFA seems to be encouraged by the inclusion of tannins in the diet, especially in the case of OA, which increased with CTE diet $(+7 \%$ in MUT and $+9 \%$ in WLT, respectively) regardless of breeds. The $\alpha$-LNA content was affected by both diet and breed effect. The FA profile in egg yolk varies considerably with the dietary ingredients, which affect the efficiency of FA transfer with particular attention to the UFA fraction (Gonzalez-Esquerra and Leeson, 2001). Even if the 
role of tannin in lipid metabolism in monogastrics is not yet completely elucidated, several authors demonstrated that hydrolysable polyphenols can limit the lipid solubility and consequently the intestinal absorption of fat (Zhao et al., 2014). For this reason, it is hypothetical that CTE could interfere with selective FA absorption at the gut level, causing a different uptake according to the FA molecular structure. The DI values, calculated as cis-9 C14:1 / total C14 FAs ratio to evaluate the index of the Stearoyl CoA gene expression in tissues, suggested that CTE could decrease the $\Delta^{9}$ desaturase activity in WL breed but not in MU. In fact, several authors demonstrated that tannins are able to interfere with gene expression in cells and that their solubility plays an important role in both inhibiting the enzymatic activity and being metabolised by cells to bioactive monomers (Landete, 2011; Buccioni et al., 2015). Despite conflicting studies about the role of cholesterol in cardiovascular diseases (Vos, 2010), some authors have proposed reducing dietary cholesterol (Plourde and Cunnane, 2007; Spence et al., 2010; Houston et al., 2011) and encouraged the production of novel foods with a low content of this lipid and high levels in Omega-3 FA, vitamin E and vitamin D (Naber, 1993; Elkin, 2007; Cherian, 2009; Kassis et al., 2010; Lawlor et al., 2010).

In the current study, the soluble tannin extract was able to reduce the cholesterol content in yolks regardless of breed. This finding could be related to cholesterol biosynthesis inhibitory activities, as a consequence of the presence of polyphenolic compounds in the diet ( $\mathrm{Lu}$ and Hwang, 2008). Unfortunately, few studies have been carried out on the effect of hydrolysable tannins on hen cholesterol metabolism. In the literature, several trials have demonstrated that a constant consumption of hydrolysable polyphenols contributes to reduced serum cholesterol concentration in monogastrics including humans and that the gallic acid moiety, present also in CTE, may play an inhibitory role in cholesterol biosynthesis or uptake (Lu and Hwang, 2008; Campo et al., 2012; Kim et al., 2013; Kobayashi and Ikeda, 2014). The WL breed seemed to be more sensitive than the MU breed to the CTE effect in reducing cholesterol content in eggs. Usually, cholesterol content in eggs from autochthonous hens is higher when compared to that in eggs from commercial laying hens based on the fact that the cholesterol content is strongly related to genetic factors, lay intensity, dietary composition and layer age (Vorlovà et al., 2001; Millet et al., 2006; Mikec and Dinarina-Sablić, 2007).

\section{CONCLUSIONS}

The dietary supplementation of CTE in a practical dose can contribute to decreasing the cholesterol and increasing the OA concentration in egg yolks.
For human consumption, eggs with a lower cholesterol content and a higher functional FA percentage could be recommended as a support to controlling heart disease. However, the MU breed seemed to be less sensitive to polyphenol dietary inclusion. In terms of egg nutritional value, an improvement of egg quality enhancing the healthy components present in the lipid fraction and, at the same time, lowering the harmful components is however desirable.

\section{ACKNOWLEDGEMENTS}

In memory of Dr Alessandro Sandrelli, a good researcher and marvellous friend.

The authors thank Mr Silvano Lancini of the "Dipartimento Di Scienze delle Produzioni AgroAlimentari e dell'Ambiente" for his precious technical assistance in animal management during the trial, the University of Florence for financing this research and Gruppo Mauro Saviola srl, Radicofani, Siena, Italy, for the provision of chestnut tannin.

\section{DISCLOSURE STATEMENT}

No potential conflict of interest was reported by the authors.

\section{FUNDING}

This work was funded by Università degli Studi di Firenze.

\section{REFERENCES}

Ahmed, A.E., Smithard, R. \& Ellis, M. (1991) Activities of enzymes of the pancreas, and the lumen and mucosa of small intestine in growing boiler cockerels fed on tannin containing diets. British Journal of Nutrition, 65: 189-197. doi:10.1079/BJN19910080

Association of Official Analytical Chemists (1995) Official Methods of Analysis. 16th edn. (Arlington, VA, AOAC).

Begovic, S., Duzic, E., Sakirbegovic, A. \& TAfro, A. (1978) Examination of tannase activity in ruminal contents and mucosa of goat fed oak leaves and during intraruminal application of 3-10\% tannic acid. Veterinary Yugoslavia, 4: 445-457.

Bole-Hribovsek, V., Drobnic-Kosorek, M., Ponebsek, J., Moran, D. \& Hooge, D.M. (2012) Minimum inhibitory concentrations of Farmatan(R) dried all-natural tannic acid (flavoring) feed additive on pathogenic strains of Clostridium perfringens and Escherichia coli plus isolates of four Salmonella species in vitro. Poultry Science, Association Annual Meeting, Athens, GA, July 9-12. Abstract P375.

Buccioni, A., Serra, A., Minieri, S., Mannelli, F., Cappucci, A., Benvenuti, D., Rapaccini, S., Conte, G. \& Mele, M. (2015) Milk production, composition, and milk fatty acid profile from grazing sheep fed diets supplemented with chestnut tannin extract and extruded linseed. Small Ruminant Research. doi:10.1016/j.smallrumers.2015.07.021

Burns, R.E. (1963) Methods of tannin analysis for forage crop evaluation. Technical Bulletin Number 32 (Athens, GA, 
Georgia Agricultural Experiment Stations, University of Georgia College of Agriculture)

Campo, M., Pinelli, P. \& Romani, A. (2012) HPLC/DAD/ESIMS characterization and antioxidant activity of sweet chestnut (Castanea sativa M.) fractions. XXI international conference of polyphenols Proceedings, Florence, 135-136.

Chang, S.I. \& Fuller, H.L. (1964) Effect of tannin content of grain sorghums on their feeding value for growing chicks. Poultry Science, 43: 30-36. doi:10.3382/ps.0430030

Cherian, G. (2009) Eggs and health: nutrient sources and supplement carriers. Complementary Alternative Therapies in the Aging Population, 1: 333-346.

Chung, K.T., Lu, Z. \& Chou, M.W. (1998) Mechanism of inhibition of tannic acid and related compounds on the growth of intestinal bacteria. Food and Chemical Toxicology, 36: 1053-1060. doi:10.1016/S0278-6915(98)00086-6

Contarini, G., Povolo, M., Pelizzola, V., Monti, L. \& Lercker, G. (2013) Interlaboratory evaluation of milk fatty acid composition by using different GC operating conditions. Journal of Food Composition and Analysis, 32: 131-140. doi:10.1016/j. jfca.2013.08.008

Cruz-Hernandez, C., Kramer, J.K.G., Kraft, J., Santercole, V., Or-Rashid, M., Deng, Z., Dugan, M.E.R., Delmonte, P. \& YuRAwecZ, M.P. (2006) Systematic analysis of trans- and conjugated linoleic acids in the milk and meat of ruminants, in: Yurawecz, M.P., Kramer, J.K.G., Gudmundsen, O., Pariza, M. W. \& Bann, S. (Eds) Advances in Conjugated Linoleic Acid Research, pp. 45-93 (Champaign, IL, AOCS Press)

Destaillats, F., Trottier, J.P., Galvez, J.M.G. \& Angers, P. (2005) Analysis of alpha-linolenic acid biohydrogenation intermediates in milk fat with emphasis on conjugated linolenic acids. Journal Dairy Science, 88: 3231-3239. doi:10.3168/jds.S0022-0302(05) 73006-X

Elizondo, A.M., Mercado, E.C., Rabinovitz, B.C. \& FernandeZNirakaWA, M.E. (2010) Effect of tannins on the in vivo growth of Clostridium perfringens. Veterinary Microbiology, 145: 308-314. doi:10.1016/j.vetmic.2010.04.003

ELKIN, R.G. (2007) Reducing shell egg cholesterol content. II. Review of approaches utilizing non-nutritive dietary factors or pharmacological agents and an examination of emerging strategies. World's Poultry Science Journal, 63: 5-31. doi:10.1017/S0043933907001249

FolCh, J., Lees, M. \& Stanley, G.H.S. (1957) A simple method for the isolation and purification of total lipids from animal tissues. Journal of Biological Chemistry, 226: 497-509.

Fuller, H.L., Chang, S. \& Potter, D.K. (1967) Detoxication of dietary tannic acid by chicks. Journal of Nutrition, 91: 477481.

Garcia, R.G., Mendez, A.A., Sartori, J.R., Paz, I.C.L.A., Takahashi, S.E., Pelicia, K., Komiyama, C.M. \& Quinteiro, R. R. (2004) Digestibility of feeds containing sorghum, with and without tannin for broiler chickens submitted to three room temperatures. Revista Brasileira de Ciência Avícola, 6 55-60. doi:10.1590/S1516-635X2004000100007

Giner-Chavez, B.J. (1996) Condensed tannins in tropical forages. Ph.D. Thesis. Cornell University, Ithaca, NY.

Gonzalez-Esquerra, R. \& Leeson, S. (2001) Alternatives for enrichment of eggs and chicken meat with omega- 3 fatty acids. Canadian Journal of Animal Science, 81: 295-305. doi:10.4141/A00-092

Houston, D.K., Ding, J., Lee, J.S., Garcia, M., Kanaya, A.M., Tylavsky, F.A., Newman, A.B., Visser, M. \& Kritchevsky, S.B. (2011) For the health ABC study, dietary fat and cholesterol and risk of cardiovascular disease in older adults: the health ABC Study. Nutrition, metabolism and Cardiovascular Diseases, 21: 430-437. doi:10.1016/j.numecd.2009.11.007

Hughes, R.J. (1972) Abnormal yolk color and mottling caused by dietary tannic acid and "tannins". Poultry Science, 52: 1784-1786. doi:10.3382/ps.0521784

Iмік, H. (2009) Effects of different proportions of sorghum (Sorghum vulgare) and methionine additions in the rations on laying performance and egg quality properties in hens. Journal. of Animal and Veterinary Advanced, 8 (2): 397-402.

Institutional Animal Care and Use Committee. (2004) University of Florence. Available: www.unifi.it.

Jacob, J.P., Mitaru, B.N., Mbugua, P.N. \& Blair, R. (1996) The feeding value of Kenyan sorghum, sunflower seed cake and sesame seed cake for broilers and layers. Animal Feed Science and Technology, 61: 41-56. doi:10.1016/0377-8401(96)00957-1

Jamroz, D., WilicZkiewicz, A., Skorupinska, J., Orda, J., Kuryszko, J. \& Tschirch, H. (2009) Effect of sweet chestnut tannin (SCT) on the performance, microbial status of intestine and histological characteristics of intestine wall in chickens. British Poultry Science, 50: 687-699. doi:10.1080/ 00071660903191059

Kassis, N., Drake, S.R., Beamer, S.K., Matak, K.E. \& Jaczynski, J. (2010) Development of nutraceutical egg products with omega-3-rich oils. Food Science and Technology International, 43: 777-783.

Kim, B., Ku, C.S., Pham, T.X., Park, Y., Martin, D.A., Xie, L., TAheri, R., Lee, J. \& Bolling, B.W. (2013) Alonia melanocarpa (chokeberry) polyphenol-rich extract improves antioxidant function and reduces total plasma cholesterol in apolipoprotein E knockout mice. Nutrition Research, 33: 403441. doi:10.1016/j.nutres.2013.03.001

KobAYASHI, M. \& IKEDA, I. (2014) Modulation of intestinal cholesterol absorption by dietary tea polyphenols, in: Watson, R.R. \& Preedy, V.R. (Eds) Polyphenols in Human Health and Desease, pp. 625-638 (University of Arizona: Academic press Elsevier)

Kramer, J.K.G., Cruz-Hernandez, C., Deng, Z.Y., Zhou, J.Q., JahreIS, G. \& Dugan, M.E.R. (2004) Analysis of conjugated linoleic acid and trans- 18:1 isomers in synthetic and animal products. The American Journal of Clinical Nutrition, 79: 1137S-1145S.

Kramer, J.K.G., Fellner, V., Dugan, M.E.R., Sauer, F.D., Mossoba, M.M. \& Yurawecz, M.P. (1997) Evaluating acid and base catalysts in the methylation of milk and rumen fatty acids with special emphasis on conjugated dienes and total trans- fatty acids. Lipids, 32: 1219-1228. doi:10.1007/ s11745-997-0156-3

Kramer, K.G., Hernandez, M., Cruz-Hernandez, C., Kraft, J. \& Dugan, M.E.R. (2008) Combining results of two GC separations partly achieves determination of all cis- and trans-16:1, 18:1, 18:2 and 18:3 except CLA isomers of milk fat as demonstrated using Ag-Ion SPE fractionation. Lipids, 43: 259-273. doi:10.1007/s11745-007-3143-4

LANDETE, J.M. (2011) Ellagitannins, ellagic acid and their derived metabolites: a review about source, metabolism, functions and health. Food Research International, 44: 11501160. doi:10.1016/j.foodres.2011.04.027

Lawlor, J.B., Gaudette, N., Dickson, T. \& House, J.D. (2010) Fatty acid profile and sensory characteristics of table eggs from laying hens fed diets containing microencapsulated fish oil. Animal Feed Science and Technology, 156: 97-103. doi:10.1016/j.anifeedsci.2010.01.003

Littell, R.C., Henry, P.R. \& Ammerman, C.B. (1998) Statistical analysis of repeated measures data using SAS procedures. Journal of Animal Science, 76: 1216-1231. doi:10.2527/ 1998.7641216x

LONGSTAFF, M. \& MCNAB, J.M. (1991a) The inhibitory effects of hull polysaccharides and tannins of field beans (Vicia faba $L$.) on the digestion of aminoacids, starch and lipid and on digestive enzymes activities in young chicks. British Journal of Nutrition, 65: 199-216.

Longstaff, M. \& McNAb, J.M. (1991b) The effect of concentration of tannin-rich bean hulls (Vicia faba L.) on the acivities of lipase (E.C. 3.1.1.3) and alpha-amylase (EC 3.2.1.1) in digesta and pancreas on the digestion of lipid and starch by young chicks. British Journal of Nutrition, 66: 139-147.

Lu, C.H. \& Hwang, L.S. (2008) Polyphenol contents of Pu-Erh teas and their abilities to inhibit cholesterol biosynthesis in 
Hep G2 cell line. Food Chemestry, 111: 67-71. doi:10.1016/j. foodchem.2008.03.043

Marzoni, M., Castillo, A. \& Romboli, I. (2005) Dietary inclusion of quebracho (Schopsis lorentzii) tannins on productive performances of growing pheasant females. Italian Journal of Animal Science, 4 (Suppl. 2): 507-509.

McNaughton, J., Roberts, M., Rice, D., Smith, B., Hong, B., Delaney, B. \& Iiams, C. (2014) Comparison of broiler performance and carcass yields when fed diets containing genetically modified canola meal from event DP- $\varnothing 73496-4$, nearisogenic canola meal, or commercial canola meals. Poultry Science, 93 (7): 1713-1723. doi:10.3382/ps.2013-03645

Mikec, M. \& Dinarina-Sablić, M. (2007) Cholesterol content in chicken eggs dependant on various breeds, age and housing types. Proceedings of the 7th symposium of poultry days 2007 with international participation, Croatian Veterinary Institute, Zagreb, pp. 112-118.

Milinsk, M.C., Mukarami, A.E., Gomes, S.T.M., Matsushita, M. \& De SouzA, N. (2003) Fatty acid profile of eggs yolk lipids from hens fed diets rich in n-3 fatty acids. Food Chemestry, $\mathbf{8 3}$ (2): 287-292. doi:10.1016/S0308-8146(03)00094-3

Millet, S., De Ceulaer, K., Van Paemel, M., Raes, K., De Smet, S. \& JansSENs, G.P.J. (2006) Lipid profile in eggs of Araucana hens compared with Lohmann selected Leghorn and ISA brown hens give diets with different fat sources. British Poultry Science, 47: 294-300. doi:10.1080/00071660600741818

Minolta (1994) Precise Color Communication. (Tokyo, Japan, Minolta Co., Ltd.)

NABER, E.C. (1976) The cholesterol problem, the egg and lipid metabolism in the laying hen. Poultry Science, 55 (1): 14-30. doi:10.3382/ps.0550014

NABER, E.C. (1993) Modifying vitamin content of eggs: a review. Journal of Applied Poultry Research, 2: 385-393. doi:10.1093/japr/2.4.385

National Research Council (1994) Nutrient Requirements of Poultry. 9th edn. (Natl. Acad. Press, Washington, DC).

North, M.O. (1984) Breeder management, in: Commercial Chicken Production Manual. (Westport, CT, The Avi. Publishing Company. Inc.). 240-243.

Panda, A.K., Rama, S.V., Raju, M.V.L.N. \& Sharma, S.V. (2008) Effect of probiotic (Lactobacillus sporogenes) feeding on egg production and quality, yolk cholesterol and humoral immune response of white Leghorn layer breeders. Journal of the Science and Food and Agriculture, 88: 43-47.

Plourde, M. \& Cunnane, S.C. (2007) Extremely limited synthesis of long-chain polyunsaturates in adults: implications for their dietary essentiality and use as supplements. Applied Physiology, Nutrition, and Metabolism, 32: 619-634. doi:10.1139/H07-034

PotTer, D.K. (1967) Effect of tannic acid on egg production and egg yolk mottling. Poultry Science, 46 (6): 1508-1512. doi: $10.3382 /$ ps.0461508

Salobir, J., Rezar, V., Frankie, T., Volje, M., Levart, A. \& Leben, S. (2008) Effects of tannins-rich extract of sweet chestnut wood on the use of nutrients in broilers. Biotechnical Faculty, University of Ljubljana, Ljubljana, Slovenia Research Final Report, 8.

SAnder, B.D., Smith, D.E., Addis, P.B. \& PARK, S.W. (1989) Effects of prolonged and adverse storage conditions on levels of cholesterol oxidation products in dairy products. Journal of Food Science, 54: 874-879.
SAS (1999) SAS/STAT User's Guide. Release 8.0 edn. (Cary, NC, SAS Institute Inc.)

SCAlBERT, A. (1991) Antimicrobial properties of tannins. Phytochemestry, 30: 3875-3883. doi:10.1016/0031-9422(91) 83426-L

Schiavone, A., Guo, K., Tassone, S., Gasco, L., Hernandez, E., Denti, R. \& Zoccarato, I. (2008) Effects of a natural extract of chestnut wood on digestibility, performance traits, and nitrogen balance of boiler chicks. Poultry Science, 87: 521527. doi:10.3382/ps.2007-00113

Sell, D.R., Rogler, J.C. \& Featherston, W.R. (1983) The effect of sorghum tannin and protein level on the performance of laying hens maintained in two temperature enviroments. Poultry Science, 62: 2420-2428. doi:10.3382/ps.0622420

Smulikowska, S., Pastuszewska, B., S`Wiech, E., Ochtabin`́ska, A., Mieczkowska, A., Nguyen, V.C. \& Buraczewska, L. (2001) Tannin content affects negatively nutritive value of pea for monogastrics. Journal of Animal Feed Science, 10: 511-523.

Spence, D.J., Jenkins, D.J.A. \& Davignon, J. (2010) Dietary cholesterol and egg yolks: not for patients at risk of vascular disease. Canadian Journal of Cardiology, 26: e336-e339. doi:10.1016/S0828-282X(10)70456-6

Sukhija, P.S. \& Palmquist, D.L. (1988) Rapid method for determination of total fatty acid content and composition of feedstuffs and feces. Journal of Agricultural and Food Chemistry, 38: 1202-1206. doi:10.1021/jf00084a019

Sweeley, C.C., Bentley, R., Makita, M. \& Wells, W.W. (1963) Gas-liquid chromatography of trimethylsilyl derivatives of sugars and related substances. Journal of the American Oil Chemists Society, 85: 2497-2507. doi:10.1021/ja00899a032

Tosi, G., Massi, P., Antongiovanni, M., Buccioni, A., Minieri, S., Marenchino, L. \& Mele, M. (2013) Efficacy test of a hydrolysable tannin extract against necrotic enteritis in challenged broiler chickens. Italian Journal Animal Science, 12 e 62: 386-389.

Trevino, J., Ortiz, L. \& Centeno, C. (1992) Effect of tannins from faba beans (Vicia faba) on the digestion of starch by growing chicks. Animal Feed Science and Technology, 37: 345349. doi:10.1016/0377-8401(92)90017-Z

Van Soest, P.J., Robertson, J.B. \& Lewis, B.A. (1991) Methods for dietary fibre, neutral detergent fibre, and no starch polysaccharides in relation to animal nutrition. Journal Dairy Science, 74: 3583-3597. doi:10.3168/jds.S0022-0302 (91) 78551-2

Vohra, P., Kratzer, F.H. \& Joslyn, M.A. (1966) The growth depressing and toxic effects of tannins to chicks. Poultry Science, 45:: 135. doi:10.3382/ps.0450135

Vorlovì, L., Sieglovì, E., Karpiskovì, R. \& Kopriva, V. (2001) Cholesterol content in eggs during the laying period. Acta Veterinaria Brno, 70: 387-390. doi:10.2754/avb200170040387

Vos, E. (2010) All-cause mortality, cholesterol and eggs. Canadian Journal of Cardiology, 27: 264 e3.

WeBer, R.E. (1970) Functional and molecular properties of corpuscular haemoglobin from the bloodworm glycera gigantea. Netherlands Journal of Sea Research, 7: 316-327. doi:10.1016/0077-7579(73)90054-9

Zhao, T., Sun, Q., Del Rincon, S.V., Lovato, A., Marques, M. \& Witcher, M. (2014) Gallotannin imposes S phase arrest in breast cancer cells and supresses the growth of triple-negative tumors in vivo. PLoS ONE, 9 (3): e9. 